\title{
Valvular heart disease \\ A study of mortality in the Sheffield population
}

\author{
S. T A L B O T ${ }^{1}$
}

The Royal Infirmary, Sheffield S6 3DA

\begin{abstract}
Talbot, S. (1973). Thorax, 28, 622-626. Valvular heart disease: a study of mortality in the Sheffield population. A study of deaths due to valve disease in the community and in hospital showed that aortic valve disease was a more common cause of sudden death than was mitral valve disease. Mitral valve disease was a frequent cause of death in the elderly, but all valve lesions in the elderly were found more often in the community than in the hospital series; these were often $(66 \%)$ undiagnosed prior to death, particularly in men. Evidence of combined aortic and mitral valve disease was less often overlooked.

Systemic embolism was an important factor influencing admission to hospital and was often the presenting feature.

The absence of physical findings was probably not responsible for the poor diagnostic rate in the community series. Auscultation of the heart in asymptomatic men and women over the age of 40 years must become widespread before there will be an improvement in mortality and morbidity of these conditions.
\end{abstract}

With improvement in the results of surgery of valvular heart disease, patients with all forms of disease are potential candidates for operation.

Mitral stenosis is not uncommon in the elderly (Hammond and Platts, 1960; Hargreaves, 1961) in whom the diagnosis is often overlooked. Studies of hospital necropsies have suggested that $25 \%$ of cases are over the age of 60 years and that $70 \%$ of such cases are diagnosed in life (Hammond and Platts, 1960). The age incidence and diagnostic accuracy may be different in patients dying at home.

Aortic stenosis is an important cause of sudden death (McGinn and White, 1934). These deaths usually occur in the community and may form a significant part of a coroner's necropsy series.

This study was undertaken to determine the number of people dying of valvular heart disease in hospital and in the community and in particular to find out the number of people dying in whom the diagnosis was not made in life. For reasons of accuracy, only cases confirmed at necropsy have been included.

\section{METHOD}

Coroner's necropsy records were examined for the period 1965 to 1971 inclusive at the Sheffield

1Present address: The Red House, Rushams Road, Horsham. 1Present
Sussex
Coroner's Office. From the causes of death, cases of valvular heart disease were selected. The pathologist's opinion as to the severity of aortic stenosis waQ accepted ; cases of mild stenosis were excluded from the analysis. If there was mitral stenosis, this was considered severe if the valve orifice did not admit finger tip, moderate if it would just admit a fingert tip, and mild if the orifice was any larger. Cases wit only mitral valve sclerosis were excluded. In addition seven cases of mild mitral stenosis were exclude because the stenosis was probably not a cause of death, but other cases of mild mitral stenosis assoge ciated with mitral incompetence or moderate of severe aortic stenosis were included as either mixed mitral valve disease or a double valve lesion. Cases of valvular incompetence alone were always included unless the incompetence was thought to be due to. ring dilatation or atheroma. The pathologist's asses ment of the degree of incompetence was accepted buP mild mitral incompetence was never recorded as D cause of death. Incompetence of severely stenosed valves was always considered to be severe.

The sex, age, date of death and history of valvular heart disease were recorded. If the patient waㅇ under hospital treatment at the time of death this was considered evidence that valvular disease has been detected. Heart weight (Zeek, 1942) and theo previous medical history were recorded when avai $\bar{b}$ able, as well as other pathology that contribute $\vec{\phi}$ to death or was a complication of valvular disease Systemic embolism was diagnosed if there was lef atrial thrombus and systemic thrombus, or if the were multiple systemic thrombi or ischaemic lesions 
These cases were compared with a group of patients dying of valvular disease at the Sheffield Royal Infirmary, whose necropsy records were also examined. The period of analysis was longer (1961-71 inclusive) because fewer patients died in hospital. In both groups any other cardiac disorders amenable to surgical treatment were noted.

\section{RESULTS}

There were 179 women and 174 men with valvular heart disease in the analysis of sudden deaths (i.e., the community group) after exclusion of 31 men and 24 women because they had been referred to the coroner after death had occurred in hospital. This series comprised $2.4 \%$ of all necropsies, but $3.2 \%$ of necropsies performed on patients who had non-violent deaths. During the seven-year period there was an increase in the number of men with aortic valve disease, but the number of people dying of mitral valve disease remained unchanged and this accounted for a rise in the proportion of men over the seven-year period.

The patients have been divided into those with aortic valve disease alone (AVD, 47.6\%); mitral valve disease alone (MVD, 33\%); and aortic and mitral valve disease (DVD 19.4\%). The mean age of men with mitral valve disease was 63.6 years and the mean age of the women was 59.6 years. However, the mean ages of the women with AVD (70.3 years) and DVD (64.9 years) were higher than those of the men $(64.9$ and 61.5 years respectively). The commonest age group at death for men with any valve lesion was 60-69 years. However, deaths due to mitral valve disease in women usually occurred in the 50-59 year age group although over twice as many women as men were over 70 years of age at death. The 70-79 year age group was the most frequent for women with AVD and DVD. Double valve disease was found three times as often in women over the age of 70 years.
In Table I the diagnostic rate in life for each valve lesion has been assessed. Aortic valve disease was frequently undiagnosed at death $(86 \%)$ in both men and women but mitral valve disease was also overlooked $(51 \cdot 4 \%)$. There were six women with tricuspid as well as mitral and aortic valve disease and these have been included in the above classification.

Sixty-one cases $(17 \cdot 3 \%)$ had complications contributing to death. Left atrial thrombus was found in 10 cases and cerebral emboli in 15 cases. Apart from cerebral emboli, systemic emboli were an infrequent cause of death. Evidence at necropsy of previous embolism was recorded in only three cases. There were three cases of acute bacterial endocarditis, one on a normal mitral valve and two on normal aortic valves. Right atrial thrombus and/or pulmonary embolism and infarction occurred in one case, and there was one other case of pulmonary embolism and infarction.

Undetected congenital heart disease was found in only five cases.

The hospital group consisted of 167 patients. However, there were 22 cases who died following mitral valvotomy, eight following aortic valve replacement, six who died after aortic and mitral valve replacement, and four who died after mitral valve replacement. To evaluate the natural history of valvular heart disease these cases were excluded, leaving 85 women and 42 men; $17 \cdot 4 \%$ had aortic valve disease, $57 \%$ had mitral valve disease, and $25.6 \%$ had double valve disease. The entire group made up $2.5 \%$ of all hospital necropsies.

There was no significant change in the number or type of patients admitted during the 11-year period. Aortic valve disease was as often undiagnosed in hospital practice as at home (see Table II). DVD was rarely missed, but the diagnostic rate for mitral valve disease was only slightly better in hospital that at home. There were only two cases with associated tricuspid valve disease.

T A B LE I

NUMBER OF MEN AND WOMEN IN COMMUNITY GROUP WITH DIFFERENT VALVULAR LESIONS DIVIDED INTO CASES DIAGNOSED IN LIFE AND CASES DETECTED AT NECROPSY

\begin{tabular}{|c|c|c|c|c|c|c|c|c|c|c|}
\hline \multirow[b]{2}{*}{ Lesion } & \multicolumn{5}{|c|}{ Diagnosed Cases } & \multicolumn{5}{|c|}{ Undiagnosed Cases } \\
\hline & Men & $\begin{array}{c}\text { Mean } \\
\text { Age } \\
(\mathrm{yr})\end{array}$ & Women & $\begin{array}{c}\text { Mean } \\
\text { Age } \\
(y r)\end{array}$ & Total & Men & $\begin{array}{c}\text { Mean } \\
\text { Age } \\
\text { (yr) }\end{array}$ & Women & $\begin{array}{c}\text { Mean } \\
\text { Age } \\
(\mathrm{yr})\end{array}$ & Total \\
\hline $\begin{array}{l}\text { Mitral valve } \mathbf{D} \text {. } \\
\text { Aortic valve } \mathbf{D} \text {. } \\
\text { Double valve } \mathbf{D} \text {. }\end{array}$ & $\begin{array}{l}12 \\
16 \\
12\end{array}$ & $\begin{array}{l}46 \cdot 5 \\
60 \cdot 9 \\
45 \cdot 3\end{array}$ & $\begin{array}{r}50 \\
7 \\
21\end{array}$ & $\begin{array}{l}53 \cdot 7 \\
56 \cdot 1 \\
58 \cdot 6\end{array}$ & $\begin{array}{l}62 \\
23 \\
33\end{array}$ & $\begin{array}{l}21 \\
93 \\
10\end{array}$ & $\begin{array}{l}69 \cdot 0 \\
62 \cdot 2 \\
67 \cdot 4\end{array}$ & $\begin{array}{l}33 \\
52 \\
26\end{array}$ & $\begin{array}{l}65 \cdot 9 \\
72 \cdot 2 \\
72 \cdot 2\end{array}$ & $\begin{array}{r}54 \\
145 \\
36\end{array}$ \\
\hline Total & 40 & $51 \cdot 7$ & 78 & $55 \cdot 2$ & 118 & 124 & $63 \cdot 8$ & 111 & $70 \cdot 2$ & 235 \\
\hline
\end{tabular}


T A B LE I I

NUMBER OF MEN AND WOMEN IN HOSPITAL GROUP WITH DIFFERENT VALVULAR LESIONS, DIVIDED INTO THREE GROUPS

\begin{tabular}{|c|c|c|c|c|c|c|c|}
\hline & \multicolumn{2}{|c|}{$\begin{array}{l}\text { Aortic } \\
\text { Valve } \\
\text { Disease }\end{array}$} & \multicolumn{2}{|c|}{$\begin{array}{l}\text { Mitral } \\
\text { Valve } \\
\text { Disease }\end{array}$} & \multicolumn{2}{|c|}{$\begin{array}{l}\text { Double } \\
\text { Valve } \\
\text { Disease }\end{array}$} & \multirow[b]{2}{*}{ Total } \\
\hline & No. & $\begin{array}{c}\text { Mean } \\
\text { Age } \\
\text { (yr) }\end{array}$ & No. & $\begin{array}{c}\text { Mean } \\
\text { Age } \\
(y r)\end{array}$ & No. & $\begin{array}{c}\text { Mean } \\
\text { Age } \\
(\mathrm{yr})\end{array}$ & \\
\hline $\begin{array}{l}\text { Undiagnosed } \\
\text { Total } \\
\text { Men } \\
\text { Women }\end{array}$ & $\begin{array}{r}15 \\
12 \\
3\end{array}$ & $\begin{array}{l}65 \cdot 0 \\
66 \cdot 5\end{array}$ & $\begin{array}{r}28 \\
8 \\
20\end{array}$ & $\begin{array}{l}63 \cdot 9 \\
69 \cdot 5\end{array}$ & $\begin{array}{l}9 \\
6 \\
3\end{array}$ & $\begin{array}{l}62 \cdot 6 \\
68 \cdot 7\end{array}$ & $\begin{array}{l}26 \\
26\end{array}$ \\
\hline $\begin{array}{l}\text { Diagnosed } \\
\text { Total } \\
\text { Men } \\
\text { Women }\end{array}$ & $\begin{array}{l}7 \\
4 \\
3\end{array}$ & $\begin{array}{l}59 \cdot 5 \\
66 \cdot 3\end{array}$ & $\begin{array}{r}43 \\
6 \\
37\end{array}$ & $\begin{array}{l}51 \cdot 4 \\
57 \cdot 5\end{array}$ & $\begin{array}{r}25 \\
6 \\
19\end{array}$ & $\begin{array}{l}49 \cdot 3 \\
54 \cdot 6\end{array}$ & $\begin{array}{l}16 \\
59\end{array}$ \\
\hline $\begin{array}{l}\text { Operation } \\
\text { Total } \\
\text { Men } \\
\text { Women }\end{array}$ & $\begin{array}{l}7 \\
6 \\
1\end{array}$ & $\begin{array}{l}46 \cdot 7 \\
53 \cdot 0\end{array}$ & $\begin{array}{r}24 \\
5 \\
19\end{array}$ & $\begin{array}{l}33 \cdot 3 \\
48 \cdot 5\end{array}$ & $\begin{array}{l}7 \\
6 \\
3\end{array}$ & $\begin{array}{l}43 \cdot 0 \\
48 \cdot 5\end{array}$ & $\begin{array}{l}17 \\
23\end{array}$ \\
\hline Total & 29 & & 95 & & 43 & & 167 \\
\hline $\begin{array}{l}\% \text { of Hospital } \\
\text { admissions } \\
\% \text { of necropsies }\end{array}$ & & $\cdot 12$ & & $\begin{array}{l}0.4 \\
1.4\end{array}$ & & $\cdot 18$ & $\begin{array}{r}0.7 \\
2.46\end{array}$ \\
\hline
\end{tabular}

${ }_{11}$ Cases on whom an operation had been performed

2 Cases that had been diagnosed in life but had not been operated upon 3 Cases that were only detected at necropsy

T A B L E I I I

COMPLICATIONS OF VALVULAR HEART DISEASE IN HOSPITAL AND COMMUNITY CASES

\begin{tabular}{|c|c|c|}
\hline Complications & Hospital Group & Community Group \\
\hline $\begin{array}{l}\text { Systemic but noncerebral } \\
\text { emboli } \\
\text { Cerebral emboli } \\
\text { Pulmonary emboli/infarction } \\
\text { Bacterial endocarditis } \\
\text { Pneumonia } \\
\text { Coronary thrombosis } \pm \\
\text { myocardial infarction } \\
\text { Other conditions (including } \\
\text { neoplasia, emphysema) } \\
\text { Total number of patients } \\
\text { with complications }\end{array}$ & $\begin{aligned} 20 & (12 \cdot 0)^{1} \\
16 & (9 \cdot 6) \\
19 & (11 \cdot 4) \\
5 & (3 \cdot 0) \\
11 & (6 \cdot 6) \\
5 & (3 \cdot 0) \\
18 & (10 \cdot 8) \\
72 & (43 \cdot 1)\end{aligned}$ & $\begin{aligned} 0 & \\
15 & (4 \cdot 2) \\
2 & (0 \cdot 6) \\
3 & (0 \cdot 9) \\
5 & (1 \cdot 4) \\
15 & (4 \cdot 2) \\
25 & (7 \cdot 0) \\
61 & (17 \cdot 3)\end{aligned}$ \\
\hline
\end{tabular}

${ }^{1}$ Percentages of the total group in parentheses

The mean ages and the age group distribution of patients with each valvular lesion were similar in hospital and community groups, but because of the greater age of patients with aortic valve disease and the smaller number of such patients in hospital statistics, the average age of hospital patients was lower than that of the community. Complications were more frequent in the hospital group (Table III). Pulmonary emboli were an important cause of death (19 cases) and probably originated in the right atrium in four cases (who had right atrial thrombus). Systemic emboli (20 cases) and cerebral emboli (16 cases) were important causes of admission. In 13 cases both were present and nine cases had both pulmonary and
T A B L E I V

PRESENCE OF VALVULAR STENOSIS AND/OR INCOMPETENCE ASSESSED AS MODERATE OR SEVERE IN HOSPITAL AND COMMUNITY GROUPS

\begin{tabular}{|c|c|c|c|c|c|c|}
\hline & \multicolumn{3}{|c|}{ Sudden Death } & \multicolumn{3}{|c|}{ Hospital $^{1}$ Death } \\
\hline & Moderate & Severe & Total & Moderate & Severe & Total \\
\hline $\begin{array}{l}\text { Mitral stenosis } \\
\text { Mitral stenosis }\end{array}$ & 13 & 41 & 54 & 5 & 39 & 44 \\
\hline $\begin{array}{l}\text { and incompet- } \\
\text { ence } \\
\text { Aortic stenosis }\end{array}$ & 11 & 8 & 19 & 2 & 16 & 18 \\
\hline $\begin{array}{l}\text { ( } \pm \text { incompet- } \\
\text { ence) }\end{array}$ & 34 & 122 & 156 & 3 & 13 & 16 \\
\hline $\begin{array}{l}\text { Aortic stenosis } \\
\text { ( } \pm \text { aortic in- } \\
\text { competence }\end{array}$ & 11 & 48 & 59 & 7 & 24 & 31 \\
\hline Mitral incom- & 11 & 40 & 39 & 7 & 24 & 31 \\
\hline $\begin{array}{l}\text { petence } \\
\text { Aortic incom- } \\
\text { petence }( \pm\end{array}$ & & & 35 & & & 8 \\
\hline $\begin{array}{l}\text { MVD) } \\
\text { Old mitral valv- }\end{array}$ & & & 21 & & & 9 \\
\hline $\begin{array}{l}\text { otomy } \\
\text { Mitral }\end{array}$ & & & 7 & & & 0 \\
\hline valve prosthesis & & & 2 & & & 1 \\
\hline Total & & & 353 & & & 127 \\
\hline
\end{tabular}

systemic emboli. There were 20 cases with left atrial thrombus, of whom nine did not have emboli.

In Table IV the valve lesions of both groups have been subdivided so that the possibility of treatment could be assessed. Patients who had had a valvotomy in the past were often described as having a scarred valve, but they have been included since the lesion was probably haemodynamically important. Mitral stenosis was diagnosed more often than mitral incompetence. Many cases of mitral and aortic stenosis would have been amenable to surgical treatment.

The heart weights of hospital cases were not significantly different from those of the community cases. Heart weights were lower in undiagnosed cases dying at home and in the patients over 70 years of age.

The final cause of death was often obscure. Since death occurred more commonly in the winter months (October to April) in the hospital group $\left(\chi^{2}=8.4 \quad p<0.01\right)$ but not in the community group, sudden deaths were probably not related to respiratory infections. There was similar seasonal variation in operative deaths.

\section{DISCUSSION}

In a coroner's necropsy study aortic valve disease was the most frequent valvular lesion recorded as a cause of death. Mitral stenosis, mixed mitral valve disease, and double valve disease were also found frequently within this group of sudden 
deaths but in decreasing frequency. Sudden death in women was as often associated with mitral as with aortic valve disease. Isolated mild lesions have been excluded and the incidence of valvular disease including such cases would have been greater. However, the lesions recorded may have been an important cause of death. In less than $25 \%$ of cases there were other causes of death, e.g., ischaemic heart disease and emphysema. Hospital deaths were usually due to MVD or DVD.

The low diagnostic rate of the community cases may be partly factitious since patients may have been known to have cardiac murmurs. However, since no action was taken and specialist advice was not sought the importance of such murmurs was overlooked and this can be considered a failure of diagnosis. The murmur of mitral stenosis may be inaudible (Wood, 1968) and murmurs are less obvious if the cardiac output is reduced. It seems unlikely that this was the explanation for the failure of diagnosis since mitral incompetence usually produces an easily audible murmur and yet this lesion was detected less frequently than mitral stenosis. The diag. nosis of valvular disease was usually made in young patients, particularly women, possibly due to more frequent medical examinations.

Valvular heart disease was not always diagnosed in the hospital cases and it seems that the frequency of this condition, particularly in the elderly, is not appreciated. Previous studies have suggested that mitral valve disease is found in $2.2 \%$ of hospital necropsies on patients aged 60 years and over (Hammond and Platts, 1960) and in 3.1\% of hospital necropsies on patients aged 50 years and over (Hargreaves, 1961). In the former series $30 \%$ were undiagnosed, but in the latter less than $5 \%$. This failure of diagnosis in the elderly is probably the main reason for the greater percentage of elderly women with mitral valve disease dying at home, although death may more often be sudden due to associated ischaemic heart disease in old age. Social factors precipitate the admission of elderly patients to hospital and would have the opposite effect on the number of old people admitted.

The actual number of people dying in the community of valvular heart disease cannot be determined since necropsy is usually ordered for legal reasons. The suddenness of death may overestimate the prevalence of valvular heart disease in the community but death certification of cases of heart failure as 'ischaemic heart disease' may make national statistics an underestimate. The
Registrar General's figures (1968) showed that in the Sheffield region and the whole country $<1 \%$ of all death certificates showed evidence of aortic and mitral valve disease. The hospital studies and this community study have all suggested that a more realistic figure is between 2 and $3 \%$, and even higher in the elderly.

Mitral valve disease has been considered a mild disease in the elderly, and long clinical histories have been cited as evidence for this (Cookson, 1949). Bedford and Caird (1960) studied hospital cases and showed that the mortality rate for such patients with cardiac failure was not worse than for patients with cardiac failure due to other causes after age adjustment. However, domiciliary and hospital cases are not identical and the natural history of the majority of patients with mitral (and aortic) valve disease without overt cardiac failure is unknown. Sudden deterioration may be due to acute pulmonary oedema and the onset of rapid atrial fibrillation (Wood, 1968). At this time atrial thrombus may form quickly with fatal cerebral or coronary embolism. The actual cause of death (and not just the findings at necropsy) cannot be determined. However, there were 60 people with mitral valve disease alone, 52 with aortic valve disease alone, and 23 with DVD below the age of 60 years in the group of sudden deaths. It is probable that in many of the elderly and most of these younger patients valvular disease was an important cause of death.

Serious ventricular arrhythmias may have been the cause of sudden death in patients with mitral as well as aortic valve disease (Bergeron, Abelmann, Vasquez-Milan, and Ellis, 1954). There was no evidence that patients dying at home had more or less severe disease than hospital cases and the degree of cardiomegaly did not seem related to the suddenness of death. Admission to hospital was often due to cerebral emboli which occur in 14 to $20 \%$ of patients with rheumatic heart disease (Szekely, 1964; Keen and Leveaux, 1958). Cerebral emboli were sometimes the cause of death in community cases, but other systemic emboli, which constitute $50 \%$ of the emboli in rheumatic heart disease (Daley et al., 1951), were only a feature of the hospital group and often drew attention to the valvular disease and were the cause of admission. The rarity of previous emboli in the community cases dying of emboli confirms that the first embolism is the one most likely to be fatal (Wood, 1968).

In view of doubt as to the aetiology of aortic valve disease no separation was made as to pathogenesis. Many cases of aortic stenosis (which was 
usually calcific) were probably congenital (Campbell, 1968; McGinn and White, 1934). Mitral and double valve lesions were rheumatic.

Calculation of standardized mortality rates showed that there were increasing numbers of deaths due to aortic and mitral valve disease with increasing age. With such correction throughout life aortic valve disease was more common in men and mitral valve disease in women. The plateau in standardized mortality rate with increasing age observed in Bristol (Puffer and Griffith, 1967) was based on death certification and these conditions are overlooked in the elderly. It therefore appears that rheumatic mitral valve disease may remain active late in life and stenosis in the elderly may not have been missed in youth. White (1951) stressed the variation in the course of mitral valve disease and White and Donovan (1967) described many cases in old age. In this study, cases aged more than 70 years at death had lower heart weights, which would be compatible with late valve involvement.

There were few symptoms in the hospital and community patients and the breathlessness described by undiagnosed patients was often recorded as due to 'asthma' or 'bronchitis'. Detection of rheumatic heart disease in such cases must be improved at home and delays in investigation and subsequent treatment reduced if any significant reduction in mortality and morbidity of these diseases is to be achieved.

Digitalization to prevent the onset of rapid atrial fibrillation, early detection of bacterial endocarditis, possibly the use of anticoagulants at the onset of atrial fibrillation to prevent the formation of loose fresh thrombus (Wood, 1968), and the use of diuretics to prevent attacks of pulmonary oedema are all medical measures that may be of value. The place of surgery for elderly patients with valvular disease is in doubt; although in certain cases satisfactory results are obtained, detailed investigation preoperatively is necessary. In younger patients surgery should always be considered.
I am grateful for the advice of Dr. D. Verel and Dr. M. Platts, and the help of Dr. Kennedy of the Department of Pathology, Sheffield Royal Infirmary. I wish to thank Dr. A. Usher of the Department of Forensic Pathology, University of Sheffield, for allowing me to examine necropsy records.

\section{REFERENCES}

Bedford, P. D., and Caird, F. I. (1960). Valvular Disease of the Heart in Old Age. Churchill, London.

Bergeron, J., Abelmann, W. H., Vasquez-Milan, H., and Ellis, L. B. (1954). Aortic stenosis: clinical manifestations and course of the disease. Archives of Internal Medicine, 94, 911.

Campbell, M. (1968). The natural history of congenital aortic stenosis. British Heart Journal, 30, 514.

Cookson, H. (1949). Mitral stenosis in later life. British Heart Journal, 11, 155.

Daley, R., Mattingly, T. W., Holt, C. L., Bland, E. F., and White, P. D. (1951). Systemic arterial embolism in rheumatic heart disease. American Heart Journal, 42, 566.

Hammond, J. D. S., and Platts, M. M. (1960). The incidence of mitral valvular disease in the elderly. British Medical Journal, 1, 691.

Hargreaves, T. (1961). Rheumatic mitral valve disease in the elderly. Incidence found at necropsy. British Medical Journal, 2, 342.

Keen, G., and Leveaux, V. M. (1958). Prognosis of cerebral embolism in rheumatic heart disease. British Medical Journal, 2, 91 .

McGinn, S., and White, P. D. (1934). Clinical observations on aortic stenosis. American Journal of Medical Science, 188, 1 .

Puffer, R. R., and Griffith, G. W. (1967). Patterns of Urban Mortality, p. 58. Pan American Health Organisation, Washington, D.C.

Szekely, P. (1964). Systemic embolism and anticoagulant prophylaxis in rheumatic heart disease. British Medical Journal, 1, 1209.

White, P. D. (1951). Heart Disease, 4th ed., p. 371. Macmillan, New York.

- and Donovan, H. (1967). Hearts: Their Long Follow Up, Chap. 4. Saunders, Philadelphia and London.

Wood, P. (1968). Diseases of the Heart and Circulation, 3rd ed., p. 628. Eyre and Spottiswoode, London.

Zeek, P. M. (1942). Heart weight. Weight of the normal human heart. Archives of Pathology, 34, 820. 